COMMENT

DOI: $10.1057 /$ s41599-018-0163-z

\title{
How to survive a crisis: reclaiming philosophy as a public practice
}

\author{
Michael D. Burroughs ${ }^{1}$
}

\begin{abstract}
Philosophy is often understood as an isolated discipline in higher education, as a form of study removed from the concerns of everyday life and the majority of the public. Although philosophy is, in one sense, a professional discipline in higher education, this conception is limiting and severely underdetermines possibilities for philosophy as a public practice. As a public practice, philosophy and those who practice it can engage with pressing problems and collaborate with stakeholders beyond the academy toward the end of improving our communities. Practicing and supporting philosophy as a public practice is important both for our communities and, ultimately, for greater understanding and appreciation of professional philosophy. Doing so, however, requires significant changes in conceptions of legitimate philosophical practice and, in turn, systems of evaluation and support for publicly engaged philosophers in our institutions and departments.
\end{abstract}

\footnotetext{
${ }^{1}$ California State University, Bakersfield, CA, USA. Correspondence and requests for materials should be addressed to M.D.B. (email: mburroughs1@csub.edu)
} 


\section{Introduction}

B eyond our college and university campuses, there is a lack of public understanding of and support for the work that philosophers do (Solomon, 2001; McIntyre, 2011). This lack of support is echoed, for example, in the desires of politicians to reduce funding for philosophy programs (and the humanities more generally) in favor of more applied, vocational lines of study (Kiley, 2013; Rappeport, 2015). Even on campus, philosophy is under threat. We are in an era of reductions in student enrollment, funding shortages, and the closure of entire academic departments (Wolff, 2010; Seltzer, 2016; Bruni, 2018; Strauss, 2018).

Taken together, the discipline and profession of philosophy is facing a crisis, one that challenges contemporary norms of philosophical practice and threatens the survival of professional philosophy as we know it. In the face of this crisis it is not sufficient to rely, alone, on claims of philosophy's intrinsic value or its essential place in the intellectual heritage of the university. We cannot ignore the challenges we face and continue with philosophy-as-usual. Rather, and while there is no single solution to these challenges, we will benefit from reclaiming a greater public role for philosophy. We should, I contend, make greater space in higher education for philosophy as a public practice and support approaches to philosophy that engage more effectively with the greater public beyond the university. Doing so, however, requires significant changes in conceptions of legitimate philosophical practice and, in turn, systems of evaluation and support for publicly engaged philosophers in our institutions and departments.

\section{Philosophy as public practice}

In some ways, my suggestion of philosophy as a public practice-a form of philosophy that engages and collaborates with stakeholders beyond the academy toward the end of improving our communities-is hardly new. Socrates engaged with citizens in the Athenian agora for the purpose of increasing virtue (Plato, 2000); Bartolomé De Las Casas (1992) confronted an era of European colonialism in the Americas, using argument and philosophical critique to protest the enslavement and genocide of indigenous peoples; Hannah Arendt $(1951,1972)$ engaged with the pressing political issues of her day, ranging from Totalitarianism and the Vietnam War to the American Civil Rights Movement; Angela Davis (2011) has and continues to practice philosophy to critique the prison-industrial complex. This list of publicly engaged philosophers, stretching from the past to present, is by no means exhaustive (for example, Bertrand Russell, Michel Foucault, and bell hooks, among many others, can be considered here). Arguing for a greater public-facing role for philosophy is, in some sense, a return to our origins, a recognition that philosophy is, most fundamentally, found in common and widespread challenges we face in social and political life. Philosophy, at its best, is responsive to these problems and challenges. Philosophy is not, historically, an isolated discipline, but a publicfacing practice of questioning, critical thinking, and expression in service of the public good.

And, yet, contemporary philosophy, if it registers for the public at all, is often seen as a rarefied practice, as hairsplitting research produced for a small community of scholars (Solomon, 2001; McIntyre, 2011). This is due, in part, to a lack of understanding of the diverse forms of work that philosophers actually do, as well as the many personal and professional benefits that studying philosophy brings (National Humanities Alliance, 2018; Weinstein, 2016). Contrary to common critiques of philosophy as impractical (or even "useless") for professional development, many philosophy majors do achieve post-degree, professional success, and are highly valued by employers for their reasoning, writing, and critical thinking abilities (Nisen, 2014; Chamberlain, 2017). Philosophy majors also secure early-career and mid-career salaries that are competitive with or even surpass many professional- or vocational-degree earners (Altonji and Zimmerman, 2017; PayScale, 2017).

But we make an error if we blame misconceptions of philosophy wholly on the public, laying a charge of willful misunderstanding at the feet of the masses. Rather, these misconceptions are due, at least in part, to still-dominant norms of philosophical practice that disincentivize communication and, in turn, mutual understanding and collaboration between professional philosophers and the communities within which they reside. For example, norms that overwhelmingly prioritize the publication and dissemination of philosophical research as articles in pay-to-read academic journals, although serving an evaluative purpose within the discipline, also reinforce a strong separation between professional philosophers and the public. Many will not or simply cannot afford to access these journals; given that this is a primary form of disseminating philosophical research, this means that the majority of the public will never see, let alone understand, the work that professional philosophers produce. In addition, privileging highly abstract and technical communication of philosophical research at academic conferences that, by and large, exclude the public, also reinforces a lack of access to and understanding of the interests and commitments of professional philosophers, even those that are germane to pressing problems in the public realm.

Many philosophers now challenge these norms and, what is more, their identification as legitimate philosophical practice as such. Some (including in public philosophy, feminist philosophy, critical philosophy of race, applied ethics, and other fields) reject disembodied abstraction and a disavowal of social and political positioning in the world as a starting point for philosophical questioning and research (Allen et al. 2008; Dotson, 2012). Others move past an exclusive reliance on academic publishing and highly technical jargon, seeking to engage the public in philosophical inquiry via more accessible forms of writing, such as openaccess blogs, op-eds, and public-facing books (Hill Collins, 2009; Corvino, 2013; Cherry, 2014, 2016). Still others challenge contemporary philosophical norms both by calling for increased interdisciplinary collaboration between the sciences and humanities within the academy (O'Rourke and Crowley, 2013; Tuana, 2013) and, also, by engaging directly with community members beyond their universities. As an example of the latter, in the United States, the philosophy for children movement-and organizations like the Philosophy Learning and Teaching Organization (PLATO) and the Institute for the Advancement of Philosophy for Children (IAPC) - has been a leader in engaging in philosophical practice with children and teachers in K-12 schools. Other organizations-such as the Public Philosophy Network (PPN) and the Society of Philosophers in America (SOPHIA)-provide avenues for philosophers to conduct interdisciplinary, publicly engaged research and to catalyze and support the growth of philosophical dialogue in our communities. In response, venues for research on and discussion of public philosophy have also grown in recent years, including the Public Philosophy Journal and Precollege Philosophy and Public Practice and the public philosophy podcasts Philosophy Bakes Bread and Hi-Phi Nation, among many others.

These efforts are valuable in their own right. They highlight alternative avenues for philosophical practice and challenge disciplinary norms that reinforce a strict separation between philosophers and communities beyond campus. They open the door for us to see the potential of philosophy as a public practice and, in turn, for greater valuation and support of philosophy by the 
public. But more needs to be done to keep this door open, to support philosophers interested in producing philosophical work within and for the greater public. As several commentators have noted (Meagher, 2013; Frodeman and Briggle, 2016) institutional structures and evaluative measures within the discipline of philosophy must change in order to support and sustain philosophy as a public practice. The efforts of individuals and organizations can fade or become unsustainable without deeper changes to the institution of philosophy itself-its norms, incentives, and institutional structures. Thus, we must think creatively and systematically about ways to better support philosophers who want to engage with problems germane to civic life, about how to make this work not merely supererogatory, but a valued form of professional philosophy.

\section{Supporting philosophy as public practice}

In the current structure of academia publicly engaged philosophers face the two lives problem. On the one hand, they must excel at the traditional requirements of teaching, research, and service needed for positive status and/or promotion in their departments. On the other hand, and at the same time, they must do the intricate and often time-consuming work required to do publicly engaged philosophy successfully. Faced with these competing interests, many philosophers (especially junior faculty who face unique pressures of job security and institutional advancement) choose to abandon or sharply reduce their publicfacing work. Despite these challenges, others feel strong obligations to use their skill sets and respective privilege for the betterment of their communities. In doing so, as Linda Martín Alcoff (2002, p. 522) notes, these faculty members "sacrifice their chance of getting tenure by intentionally doing the sort of things that they know are not likely to be recognized as scholarly achievement," including building university-community partnerships, engaging in activism, and creating opportunities-whether via forums, panels, or workshops-for dialogue and collective action on topics of import to the community. As things stand in professional philosophy, then, engaging in philosophy as public practice often requires significant sacrifices in one's career, a disproportionate workload, and, overall, a burden that many cannot or will not bear (Dotson, 2012).

Fortunately, there are potential responses to these challenges, albeit responses that call for significant changes in disciplinary norms and evaluation practices. In order to support philosophy as a public practice, the dominant criteria used to evaluate philosophical work and determine promotion and status in the discipline need to be revised. Public philosophy does not find a comfortable fit within traditional evaluations of philosophical work as either research, teaching, or service (Alcoff, 2002; Meagher, 2013; Meyers, 2014). When it is credited in evaluations, public philosophy is generally counted as service; this means that it counts (in terms of job security and retention and promotion criteria) for little at all. Further, the classification of public philosophy as service is, by itself, inaccurate; this classification dismisses the time-consuming program development, research, and pedagogy (among other elements) that ground high quality forms of publicly engaged philosophy.

To take one example, I regularly practice philosophy in K-12 schools, working with teachers and students to implement philosophy discussions, activities, and lessons in classrooms. I engage in this public practice for several reasons. For one, philosophy is a valuable addition to K-12 curricula that provides beneficial education outcomes for students (Trickey and Topping, 2004; Millett and Tapper, 2012; Philosophy Learning and Teaching Organization, 2016). Second, introducing philosophy to children and teens has a reflexive impact on the discipline of philosophy, potentially leading to a greater appreciation of philosophy in the public and, more specifically, to incoming undergraduates having a greater understanding of and desire to study philosophy. Third, I simply enjoy engaging in philosophical dialogue with children who, many more times than not, are eager to engage in questioning and exploration of philosophical concepts and problems (Wartenberg, 2009; Mohr Lone, 2012; Mohr Lone and Burroughs, 2016).

In order to do this work well, I cannot simply "drop in," oblivious to the dynamics of the classroom, school culture, and teacher-student relationships. Before leading any philosophy sessions with children, I aim to learn about the school culture, meet the classroom teacher(s), observe classes and build relationships. I spend extensive time in classrooms leading discussions with children, developing lessons, and refining my plan. In addition, years spent researching child cognitive and moral development informs my practice and the materials I use to facilitate philosophical discussions with children. These activities (aside from any resulting publications) will generally be classified as service in my faculty evaluation. Thus, I, like many of my colleagues, am left in a difficult position. For the sake of time and something approaching a life-work balance, I must either choose between public philosophy and traditional teaching, research, and scholarship, or attempt to manage both at a high level.

But by shifting evaluation criteria to acknowledge the work of public philosophers and the labor it involves-labor that often runs across or beyond classifications of research, teaching, and service-we can avoid, or at least reduce, this conflict and the difficult choice it presents to professional philosophers. We can start to better understand and classify forms of philosophy as public practice (Weinstein, 2014; Burroughs and Valentine, forthcoming) and, in turn, credit this work properly in our evaluations. To this end, additional evaluation measures can be introduced for publicly engaged philosophy, including (but not limited to) letters from relevant community members and organizations, colleague observations, and written program descriptions with attention to outcomes and impacts. Alongside these changes, several commentators (Alcoff, 2002; Meyers, 2014; Frodeman and Briggle, 2016) note the importance of advocating for and educating others about the value of publicly engaged philosophy, both for our communities and, also, for the enrichment of philosophical work in the academy.

At this point, one might agree that revising promotion and evaluation criteria would provide greater institutional support for professional philosophers to engage in public practice, and, yet, still balk at the idea of this change. This is because, one might say, practicing philosophy in the public realm-in schools, prisons, community forums, through op-eds, and other avenues-while valuable work, is not actually philosophy. There is good reason, the argument will go, to keep disciplinary norms and means of evaluation as they are given that they measure the distinctive work of the professional philosopher.

To be clear, I have no qualms with the continuation of philosophical practice in the forms of publishing research in academic journals, conference presentations, and specialized philosophical research, more generally. These forms of philosophy are valuable, too, and serve an important role in the academy. My claim is a more limited one: these practices do not constitute legitimate philosophical practice as such and, thus, evaluations and forms of institutional support for philosophical work should not focus on and, in turn, support them exclusively. Rather, we should also recognize and support possibilities for other forms of meaningful, rigorous philosophical work, including those that benefit communities beyond campus and foster greater public appreciation of philosophy.

As Philip Kitcher (2011, p. 252) notes, "philosophy grows out of an impulse toward understanding nature and the human place 
in it." Philosophy is, at its core, a practice of asking questions that are fundamental to the human condition, about the nature of right and wrong, meaning, and what we can know about our world, ourselves and others (Nagel, 1987). These conceptions of philosophy point to its fundamental place in the human condition. Questions and desires for understanding were present well before the dawn of academic philosophy and the modern research university; they will remain long after these historically situated practices and institutions have passed.

With this broader view of philosophy in mind, we can see, again, the value of philosophy as a public practice and the benefits of supporting it in our institutions. When practiced well, public philosophy can reduce the intellectual and physical space between professional philosophers and community members. It can increase mutual understanding and unite these groups in efforts to address shared issues of importance, whether in education, activism, politics, or the environment. In its diverse manifestations in the present, philosophy as a public practice promotes an understanding and appreciation of philosophy in our communities and prevents the reification of philosophy as the domain of professional philosophers alone.

\section{Concluding remarks: reclaiming philosophy as a public practice}

My discussion of and justifications for supporting philosophy as a public practice are not exhaustive. Publicly engaged philosophy can also benefit philosophy teaching in the university, helping us to trace practical connections to philosophical concepts for students and provide concrete examples of the importance of philosophy beyond the classroom (Meyers, 2014). Public philosophy assists in the achievement of community engagement and public service missions espoused by many universities. And, further, the intellectual work of the philosopher can be enhanced by public engagement. Philosophy as a public practice is not merely a service that professional philosophers bring, pre-formed, to their communities; rather, it is a reciprocal process of theory and practice (or praxis). Discussing this process and its intellectual benefits, Alcoff (2002, p. 530) notes, "in public interactions, one expands one's knowledge base, learns new social criticisms, gains insights, tests claims, and develops previously unconsidered problematics."

As noted above, publicly engaged philosophy, is, in some sense, a return to our origins as professional philosophers. For several reasons, I have argued that we should reclaim philosophy as a public practice in the present. Doing so can benefit the discipline of professional philosophy and our communities while also supporting creative, new applications of philosophical research and pedagogy. In order to realize these benefits, however, we must do more than applaud the efforts of philosophers and organizations practicing public philosophy. We must also make significant changes to conceptions of legitimate philosophical practice and, in turn, systems of evaluation and support for publicly engaged philosophers in our institutions and departments.

Received: 29 June 2018 Accepted: 13 August 2018

Published online: 28 August 2018

\section{References}

Alcoff LM (2002) Does the public intellectual have intellectual integrity? Metaphilosophy 33(5):522-534

Allen A, Maaza Man A, Marcano D, Moody-Adams M (2008) Situated Black women's voices in/on the profession of philosophy. Hypatia 23(2):160-189
Altonji J, Zimmerman S (2017) The costs of and net returns to college major http://www.nber.org/papers/w23029. Accessed 26 June 2018

Arendt H (1951) The origins of totalitarianism. Harvest: San Diego

Arendt H (1972) Crises of the republic. Harvest: San Diego

Bruni F (2018) Aristotle's wrongful death. New York Times Sunday Review. https://www.nytimes.com/2018/05/26/opinion/sunday/college-majorsliberal-arts.html. Accessed 12 June 2018

Burroughs M, Valentine D Toward engaging a broader public: children and public philosophy. Public Phil J (in press)

Chamberlain T (2017) A case for majoring in philosophy. Forbes. https://www. forbes.com/sites/noodleeducation/2017/03/01/a-case-for-majoring-inphilosophy/\#440c6b835315. Accessed 26 June 2018

Cherry M (2014) Why love is not all we need. HuffPost. https://www huffingtonpost.com/myisha-cherry/why-love-is-not-all-we-ne_b_5614573. html. Accessed 12 June 2018

Cherry, M. (2016). Why is somepeople's political anger considered real while others' is not? HuffPost. https://www.huffingtonpost.com/myisha-cherry/ why-are-some-peoples-poli_b_9311418.html. Accessed 12 June 2018

Corvino J (2013) What's wrong with homosexuality? Oxford University Press: Oxford

Davis A (2011) Are prisons obsolete? Seven Stories Press: New York

De Las Casas B (1992) A short account of the destruction of theindies. Penguin, London, Translated by N. Griffin

Dotson K (2012) How is this paper philosophy? Comp Philos 3(1):3-29

Frodeman R, Briggle A (2016) Socrates tenured. The institutions of 21st-century philosophy. Rowman and Littlefield, London

Hill Collins P (2009) Another kind of public education. race, schools, the media, and democratic possibilities. Beacon Press, Boston

Kiley K (2013) Another liberal arts critic. Inside Higher Ed. https://www. insidehighered.com/news/2013/01/30/north-carolina-governor-joins-chorusrepublicans-critical-liberal-arts. Accessed 12 June 2018

Kitcher P (2011) Philosophy inside out Metaphilosophy 42(3):248-260

McIntyre L (2011) Making philosophy matter-or else. The Chronicle Review. https://www.chronicle.com/article/Making-Philosophy-Matter-or/130029. Accessed 12 June 2018

Meagher S (2013) Public philosophy: revitalizing philosophy as a civic discipline. http://api.ning.com/files/C75Xw4bA4cU7vHOHSzlLRmkdBskXa9IzuVBCJKtjhmSgMrQy8tWTu1s9vqumPuG2gyJfaPzwWJ1Tu4 ${ }^{*}$ NoJIUVYUXtPpC37/KetteringreportfinalcorrectedFeb2013.pdf. Accessed 13 June 2018

Meyers C (2014) Public philosophy and tenure/promotion: rethinking "teaching, scholarship, and service". Essays Philos 15(1):58-76

Millett S, Tapper A (2012) Benefits of collaborative philosophical inquiry in schools. Educ Phil Theory 44(5), 546-566

Mohr Lone J (2012) The Philosophical Child. Rowman \& Littlefield: Lanham

Mohr Lone J, Burroughs M (2016) Philosophy in education: questioning and dialogue in schools. Rowman \& Littlefield, Lanham

Nagel T (1987) What does it all mean? Oxford University Press: Oxford

National Humanities Alliance (2018) Study the Humanities Toolkit. https://www. studythehumanities.org/toolkit. Accessed 12 June 2018

Nisen M (2014) 9 Famous Execs Who Majored in Philosophy. Business Insider. http://www.businessinsider.com/successful-philosophy-majors-2014-1?op=1. Accessed 26 June 2018

O'Rourke M, Crowley S (2013) Philosophical intervention and cross-disciplinary science: the story of the toolbox project. Synthese 190(11):1937-1954

PayScale (2017) Highest Paying Bachelor's Degrees by Salary Potential. https:// www.payscale.com/college-salary-report/majors-that-pay-you-back/ bachelors? page $=33$. Accessed 26 June 2018

Philosophy Learning and Teaching Organization (2016) Why Philosophy? Why Now?. https://www.plato-philosophy.org/wp-content/uploads/2016/06/platowhite-paper-why-philosophy-why-now.pdf. Accessed 26 June 2018

Plato (2000) The trial and death of socrates. 3rd edn (Trans: Grube GMA) Hackett, Indianapolis

Rappeport A (2015) Philosophers (and Welders) React to Marco Rubio's Debate Comments. The New York Times. https://www.nytimes.com/politics/firstdraft/2015/11/11/philosophers-and-welders-react-to-marco-rubios-debatecomments/. Accessed 12 June 2018

Seltzer R (2016) The philosophy of what makes a university. Inside Higher Ed https://www.insidehighered.com/news/2016/06/14/questions-raised-aboutcuts-liberal-arts-programs-western-illinois. Accessed 12 June 2018

Solomon R (2001) What is philosophy? The status of world philosophy in the profession. Philos East West 51(1):100-104

Strauss V (2018) A University of Wisconsin Campus Pushes Plan to Drop 13 Majors-Including English, History, and Philosophy. The Washington Post. https://www.washingtonpost.com/news/answer-sheet/wp/2018/03/21/ university-of-wisconsin-campus-pushes-plan-to-drop-13-majors-includingenglish-history-and-philosophy/?noredirect $=$ on\&utm_term $=. \mathrm{fb} 724536 \mathrm{~d} 54 \mathrm{a}$. Accessed 12 June 2018 
Trickey S, Topping K (2004) Philosophy for children: a systematic review. Res Pap Educ 19:365-380

Tuana N (2013) Embedding philosophers in the practice of science: bringing humanities to the sciences. Synthese 190(11):1955-1973

Wartenberg T (2009) Big ideas for little kids. Teaching philosophy through children's literature. Lanham, Rowman \& Littlefield

Weinstein J (2016) Philosophy is a great major. https://philosophyisagreatmajor. com. Accessed 12 June 2018

Weinstein J (2014) What does public philosophy do? (Hint: it does not make better citizens). Essays Philos 15(1):33-57

Wolff J (2010) Why is Middlesex University Philosophy Department Closing? The Guardian. https://www.theguardian.com/education/2010/may/17/philosophyclosure-middlesex-university. Accessed 12 June 2018

\section{Acknowledgements}

The author thanks Ms Roberta Israeloff and Dr Christopher Meyers for their helpful feedback on drafts of, and ideas for, this article. In addition, the author thanks the many philosophers doing innovative, community-engaged work in the public realm. You have been the main source of inspiration for this article.

\section{Additional information}

Competing interests: The author declares no competing interests
Reprints and permission information is available online at http://www.nature.com/ reprints

Publisher's note: Springer Nature remains neutral with regard to jurisdictional claims in published maps and institutional affiliations.

\section{(c) (i)}

Open Access This article is licensed under a Creative Commons Attribution 4.0 International License, which permits use, sharing, adaptation, distribution and reproduction in any medium or format, as long as you give appropriate credit to the original author(s) and the source, provide a link to the Creative Commons license, and indicate if changes were made. The images or other third party material in this article are included in the article's Creative Commons license, unless indicated otherwise in a credit line to the material. If material is not included in the article's Creative Commons license and your intended use is not permitted by statutory regulation or exceeds the permitted use, you will need to obtain permission directly from the copyright holder. To view a copy of this license, visit http://creativecommons.org/ licenses/by/4.0/.

(C) The Author(s) 2018 